\title{
Bureaucratic Reform: A Case Study in Secretariat General of the Ministry of Education and Culture
}

\author{
Muhammad Qudrat Wisnu Aji \\ Sekretariat Jenderal Guru dan Tenaga Kependidikan \\ Email: wisnu.aji@kemdikbud.go.id
}

(Received: October 10-2019; revised: December 4-2019; published: December 31-2019)

\begin{abstract}
Bureaucratic reforms are remedial steps to government tasks and public services, building good governance. The scope of bureaucratic reforms involves not only processes and procedures, but also changes in organizational structure and mindset and behavior of the implementers. The aim of the study is to evaluate the implementation of bureaucratic reform policies carried out by the Secretariat General of the Ministry of Education and Culture. The purposive survey method is used in this study. 80 Echelon III and IV officials in the bureaus within the Secretariat General of the Ministry of Education and Culture participated in this study. The questionnaire was used as an instrument to collect the data in this study. There are three dimensions of bureaucratic reforms examined, namely the basis of reform, the agent of reform and the bureaucratic environment. It was found that bureaucratic reforms significantly influence organizational performance at the Secretariat General of the Ministry of Education and Culture. Bureaucratic reforms are characterized by a good basis of reforms, a strengthening of Human Resources as an agent of bureaucratic reforms and a conducive environment to support the success of bureaucratic reforms to be achieved by the Ministry of Education and Culture.
\end{abstract}

Keywords: Bureaucratic reform, basis of reform, agent of reform, environmental reform

\section{INTRODUCTION}

Management and public administration are about the institutionalization and structuring arrangement. Structural is integral to all organizations. Structural reforms change the dominant system that touches key elements. Most structural reforms have not touches public administration and its core elements such as the bureaucracy (Mukhtar, 2015). On one hand, bureaucratic studies are complex because they are related to various aspects, such as institutions, human resources, systems and procedures created and carried out by the bureaucracy, as well as aspects of bureaucratic renewals or bureaucratic reforms (Yusriadi \& Misnawati, 2017).

Bureaucratic reforms are defined as a practice of power that operates through a discursive process, namely the creation of truth claims on certain reform models, which are then followed by disciplinary practices to change the behaviors of bureaucrats (Paskarina, 2017). Bureaucratic reforms are aimed at producing public services that are responsive to change, impartial, and professional in meeting and serving public interests. In other words, bureaucratic reforms are steps to improve government tasks and public services, develop governance that is free of corruption, collusion and nepotism, form professional state apparatuses, and develop more effective and efficient organizations (Aji, Heru, \& Turmudzi, 2013).

The scope of bureaucratic reforms involves not only processes and procedures, but also 
204 Jurnal Ilmiah Ilmu Administrasi Publik: Jurnal Pemikiran dan Penelitian Administrasi Publik Volume 9 Number 2,July - December 2019. Page 203-212

changes in organizational structure and mindset and behavior of the implementers. Bureaucratic reforms are top down, so to realize a sustainable process of bureaucratic reforms requires regulations that can cover and provide clear direction for ministries and institutions in implementing them. Without strict regulations, the policies and programs of bureaucratic reforms in ministries and institutions are not well integrated, which results in inconsistencies, collisions, and confusion in their implementation by both the institution and the implementing agency (Aji et al., 2013).

The process of bureaucratic reforms has become a focus in various fields and in many countries as a form of service change towards a better direction like the bureaucratic reform carried out by Jordan to improve its bureaucratic system that has no a clear career path, no relationship between career training and career advancement, has discretionary promotion that depends on ethnicity, lacks recognition of services and incentives for good jobs (Kassay, 1998). Developing countries like Indonesia, in general, are still highlighted as organizations that have not fully implemented public services. Studies on bureaucratic reforms in Indonesia have been done by several researchers, such as the study on bureaucratic reforms in Integrated Licensing Services in Bone Regency (Yusriadi \& Misnawati, 2017), one-stop administration system services in Gorontalo City (Aneta, Aneta, \& Dama, 2018), and the best-practice bureaucratic reform from various other regions in Indonesia (Prasojo \& Kurniawan, 2008).

In general, the obstacle faced by Indonesia is that many bureaucrats are not ready to change. This condition resulted in the quality of public services received far from public expectations (Tandi Datu \& Nawawi, 2014). Public administration and policy practices in Indonesia are still influenced by the classical paradigm that relies on the top-down hierarchical approach. Government bureaucratic activities should start from a policy, planning and the implementation of the policy, including public services. Yet, there is no evaluation, and, therefore, there is no feedback to policy makers and decision makers. Therefore, this study was conducted to evaluate the implementation of bureaucratic reform policies conducted by the Indonesian government through surveys. The focus of the survey is on the Secretariat General of the Ministry of Education and Culture. It is expected that this survey provides updated information and feedbacks on bureaucratic reform policies carried out at the Secretariat General of the Ministry of Education and Culture.

\section{METHOD}

The purposive survey method is used in this study. The study was conducted at the Secretariat General of the Ministry of Education and Culture. The population members in this study were 80 people, consisting of echelon III and IV officials in the bureaus within the Secretariat General of the Ministry of Education and Culture. Due to this number, the census technique was used in the collecting respondents by involving all members of the population as the respondents. The number of echelon III and IV officials in the bureaus at the Secretariat General is presented in Table 1. The questionnaire was used as an instrument to collect the data in this study. There are three dimensions of bureaucratic reforms examined, namely the basis of reforms, the reform agent and the environment. The questionnaire blueprint used is presented in Table 2. 
Table 1.

Member of Population

\begin{tabular}{clccc}
\hline No & \multicolumn{1}{c}{ Work Unit } & Echelon III & Echelon IV & Number \\
\hline 1 & General Bureau & 4 & 12 & 16 \\
& Bureau Planning and International & 4 & 12 & 16 \\
2 & Cooperation & & & 16 \\
3 & Financial Bureau & 4 & 12 & 16 \\
4 & Personnel Bureau & 4 & 12 & 16 \\
5 & Law and Organization Bureau & 4 & & 80 \\
\hline & Total & & &
\end{tabular}

Table 2.

Bureaucratic Reform Questionnaire Blueprint

\begin{tabular}{cllll}
\hline Variable & \multicolumn{1}{c}{ Dimension } & \multicolumn{1}{c}{ Indicator } & $\begin{array}{c}\text { No } \\
\text { Item }\end{array}$ \\
\hline $\begin{array}{c}\text { Bureaucratic } \\
\text { Reforms }\end{array}$ & Basis of reform; & a. Service provider staff & 1 \\
& & b. Budgeting system performance & 2 \\
& c. Organizational structure & 3 \\
& reform; & a. Support of all elements & 4 \\
& & b. Systematic employeetraining & 5 \\
& Environment & c. Recruitment system & 6 \\
& & a. Legislative pressure & 7 \\
& & b. Institutional relations & 8 \\
& & c. Legislative demands & 9 \\
& & d. Systemic relationship & 10 \\
& & e. Human resource relations & 11
\end{tabular}

\section{RESULT AND DISCUSSION}

The conditions of bureaucratic reforms are analyzed using a questionnaire consisting of 11 statements, each of which is accompanied by five possible answers to choose and consider according to the respondents. The bureaucratic reform variable has three categories, namely the basis of reform category, the agent of reform category, and the environmental category.

\section{Basis of Reform}

The basis of reforms is the first dimension of bureaucratic reforms, which is represented by three statements. The maximum score range of 80 respondents with three statements is $S_{\max }=$ 1200 while the minimum score obtained is $S_{\min }=240$. The scores are then classified according 
206 Jurnal Ilmiah Ilmu Administrasi Publik: Jurnal Pemikiran dan Penelitian Administrasi Publik Volume 9 Number 2,July - December 2019. Page 203-212

to Table 3. The scores obtained based on the survey on respondents are shown in Table 4 .

Table 3

Total Score Classification

\begin{tabular}{lll}
\hline No & Total Score & Classification \\
\hline 1 & $\mathrm{x} \leq 240$ & Very Low \\
2 & $240<\mathrm{x} \leq 480$ & Low \\
3 & $480<\mathrm{x} \leq 720$ & Moderate \\
4 & $720<\mathrm{x} \leq 960$ & High \\
5 & $\mathrm{x}>960$ & Very High \\
\hline
\end{tabular}

\section{Table 4}

\section{Total Scores of Basis of Reform Dimension}

\begin{tabular}{clc}
\hline No & \multicolumn{1}{c}{ Statements } & Total Scores \\
\hline 1 & $\begin{array}{l}\text { As the employee of the Ministry of Education and Culture, I support } \\
\text { the implementation of bureaucratic reforms by providing optimal }\end{array}$ & 360 \\
services. & $\begin{array}{l}\text { The Ministry of Education and Culture's budgeting system has been } \\
\text { allocated efficiently, effectively, accountably and measurably as a } \\
\text { prerequisite for implementing bureaucratic reforms. }\end{array}$ & 303 \\
3 & $\begin{array}{l}\text { Organizational restructuring. which is one of the bureaucratic reform } \\
\text { agendas, has made the Ministry of Education and Culture the right } \\
\text { function and right sizing. }\end{array}$ & 317 \\
\hline & Total & $\mathbf{9 8 0}$ \\
\hline
\end{tabular}

Based on Table 4, the score obtained for the basis of reforms of the survey of respondents is 980 . This score is classified as very high. The success of bureaucratic reforms is indicated by a strong basis of reforms by strengthening the staff as service providers (Lee, 1970), where the substance, levels of complexity, and goals of reforms are the focus of attention and are related to the strategy and implementation of reforms (Miftah, 2008)

The performance of the budgeting system is one of the basic indicators of bureaucratic reforms. The budgeting system provides an overview of the interrelationships between programs, goals and strategies. This can be a multilevel benchmark (Lee, 1970) between facilities and strategies (Morgan, 1997) followed by programs (Sobirin, 2007). The data in Table 4 state that the basis for bureaucratic reforms is determined by the existence of an organizational structure that has the right function and sizing (Robbins, 1990; 1998; 2003; 2009 Morgan, 1997; Gibson, 1997).

In general, the findings regarding the basis of reform dimension in the Secretariat General of the Ministry of Education and Culture have been good. This indicates that the employees have tried to provide good service, the event budget has been planned and distributed well and the existing organizational structure has been run to the maximum.

\section{Agent of Reform}


Agent of reforms is the second dimension of bureaucratic reforms. This dimension is represented by three statements. The maximum score range of 80 respondents with three statements is $S_{\max }=1200$ while the minimum score obtained is $S_{\min }=240$. The scores are then classified according to Table 3 . The scores obtained based on the survey on respondents are shown in Table 5 .

\section{Table 5}

\section{Total Scores of Agent of Reform Dimension}

\begin{tabular}{clc}
\hline No & \multicolumn{1}{c}{ Statements } & Total Scores \\
\hline 1 & $\begin{array}{l}\text { As the employee of the Ministry of Education and Culture, I have } \\
\text { understood the goals, objectives and programs of bureaucratic reforms } \\
\text { through intensive training/socialization. }\end{array}$ & 290 \\
2 & $\begin{array}{l}\text { The success of bureaucratic reforms within the Ministry of Education } \\
\text { and Culture is marked by the emergence of agents of change. }\end{array}$ & 251 \\
3 & $\begin{array}{l}\text { The emergence of agents of change in the Ministry of Education and } \\
\text { Culture is not the result of a transparent and competitive employee } \\
\text { recruitment system. }\end{array}$ & 242 \\
\hline & Total & $\mathbf{7 8 3}$ \\
\hline
\end{tabular}

Based on the table above regarding the bureaucratic reform variable, the agent of reform dimension is in the high category. In the statement that the support of all elements in carrying out bureaucratic reforms is an absolute prerequisite (Lee, 1970), this support leads to the strengthening of human resources (Caiden, 1991).

In the statement 2 that the success of bureaucratic reforms requires the existence of agents of change that act as role models at all levels of the organization, this role will save the bureaucratic position and minimize bureaucratic "red tape" that seeks to weaken its image (Dwiyanto, 2011).

A transparent and competitive employee recruitment system is a strong foundation for the emergence of agents of change in every organization that play a role in dynamically strengthening the elements of bureaucratic reforms that creates a "role model" in every level of decision making (Dwiyanto, 2011).

The findings show that in the implementation, the support from various parties is necessary to accelerate the implementation of bureaucratic reform and to realize better changes in every organization in the Ministry of Education and Culture.

\section{Bureaucratic Environment}

The environment is the third dimension of bureaucratic reforms and this category is represented by five statements. The maximum score range of 80 respondents with five statements is $S_{\max }=2000$ and the minimum score obtained is $S_{\min }=400$. The scores are then classified according to Table 6 . The scores obtained based on the survey on respondents are shown in Table 7. 
208 Jurnal Ilmiah Ilmu Administrasi Publik: Jurnal Pemikiran dan Penelitian Administrasi Publik Volume 9 Number 2,July - December 2019. Page 203-212

Table 6

Total Score Classification

\begin{tabular}{lll}
\hline No & Total Score & Classification \\
\hline 1 & $\mathrm{x} \leq 400$ & Very Low \\
2 & $400<\mathrm{x} \leq 800$ & Low \\
3 & $800<\mathrm{x} \leq 1200$ & Moderate \\
4 & $1200<\mathrm{x} \leq 1600$ & High \\
5 & $\mathrm{x}>1600$ & Very High \\
\hline
\end{tabular}

Table 7

Total Scores of Bureaucratic Environment Dimension

\begin{tabular}{llc}
\hline No & \multicolumn{1}{c}{ Statements } & Total Scores \\
\hline 1 & $\begin{array}{l}\text { The success of bureaucratic reforms is indicated by a balance between } \\
\text { environmental demands and interests. }\end{array}$ & 317 \\
2 & $\begin{array}{l}\text { Bureaucratic reforms have strengthened institutional relations within } \\
\text { the Ministry of Education and Culture which is characterized by an } \\
\text { increasingly conducive bureaucratic climate. }\end{array}$ & 325 \\
3 & $\begin{array}{l}\text { The diminishing legislative demand is the success of reforms within } \\
\text { the Ministry of Education and Culture. } \\
\text { The success of bureaucratic reforms within the Ministry of Education } \\
\text { and Culture is systemically influenced by increasingly strong } \\
\text { institutional relations. } \\
\text { Human resource relations do not affect the success of bureaucratic } \\
\text { reforms at the level of decision making. }\end{array}$ & 263 \\
\hline & \multicolumn{1}{c}{ Total } & $\mathbf{1 5 2 6}$ \\
\hline
\end{tabular}

Based on Table 7, the bureaucratic environment category of bureaucratic reforms is classified as high. Regarding the statement that the success of bureaucratic reforms is indicated by the balance between environmental demands and interests (Lee, 1970), this condition allows the synergy between organizational and public expectations (Cheung, 2005; Morgan, 2011)

Institutional relations are characterized by the strengthening of an increasingly conducive bureaucratic environment (Lee, 1970). Institutional relations are the basis of bureaucratic reforms (Miftah, 2008), which can be seen from the strengthening of organizational systems and behaviors so that this relationship gives a role for leaders to be more confident.

The diminishing legislative intervention is the success of reforms at the executive level, where the balance system between the dominant bureaucracy and the political domination (Sondang, 1995) will strengthen the role of bureaucratic reforms as the driver of the organization's ability for better changes (Miftah, 2000).

Institutional systemic relationship is one of the environmental demands in bureaucratic reforms. $62.5 \%$ of the respondents agree with the statement. This condition is in line with the view that a bureaucratic reform restores inter-bureaucratic relations (Turner and Hulme, 1997), 
where the institutional approach adds values to the potential for bureaucratic reforms (Caiden, 1991).

The relationship of human resources has little influence on the success of bureaucratic reforms at the level of decision making (Sondang, 1995; Tjokroamidjojo, 1997). This really makes sense because bureaucratic reforms shape changes in the organizational structure and culture. The findings show that a conducive environment has an important role in supporting the success of the bureaucratic reform that the Ministry of Education and Culture wants to achieve.

Internal bureaucratic reforms of the Ministry of Education and Culture are one of the government's priority agenda by making some improvements in order to improve the performance and the image of the bureaucracy which has been less than optimal in carrying out its duties. Not only are bureaucratic reforms within the Ministry of Education and Culture intended to improve the performance and the image of the educational bureaucracy, but public also have a very high expectation that the reforms will improve the quality of education through affirmative policies towards the general public.

Bureaucratic reforms can be interpreted as an effort to carry out fundamental reforms in the government system, to eliminate elements that are not good and add things that are good in accordance with the needs of the times, especially those relating to aspects of the organization, business processes, and human resources. Bureaucratic reforms are implemented to form good governance. In other words, bureaucratic reforms are a strategic step to build the state apparatus to be more efficient and effective in carrying out the tasks of governance and community services. The scope of bureaucratic reforms is not only limited to processes and procedures, but also links changes to the level of structures, attitudes and behaviors of the implementers. This is related to problems that intersect with authority and power (Aji et al., 2013). If bureaucratic reforms are successfully implemented, the expected benefits are as follows: (1) Reducing and ultimately eliminating all types of abuse of authority by the state apparatus in related institutions; (2) Making the state have the best state bureaucracy system; (3) Improving the quality of services to the society; (4) Improving the quality of the planning and implementation system of each program in each institution; (5) Increasing efficiency (cost and time) in all aspects of organizational tasks; and (6) Making the Indonesian bureaucracy more anticipative, proactive, and effective in the face of globalization and dynamic environmental changes.

The implementation of bureaucratic reforms can run well if carried out with the management of change steps. Management of change is the process of diagnosing, initiating, implementing, and integrating changes in individuals, groups, or organizations in order to adapt and anticipate changes in their environment so that they continue to grow, develop, and produce profits. Among the most common, there are seven steps of management of change. The first is mobilizing the energy and commitment of the members of the organization through the determination of the ideals, challenges, and solutions by all members of the organization. At this stage, each line in the government agency must know what the agency is dreaming about, what they are facing, and how to deal with or solve the problem together. In trigger them to run a joint solution; they need to be involved in discussions and decision making. The second is developing a shared vision, how to organize and organize themselves and institutions in order to achieve what they aspire to. The last is determining leadership (Aji et al., 2013) 
210 Jurnal Ilmiah Ilmu Administrasi Publik: Jurnal Pemikiran dan Penelitian Administrasi Publik Volume 9 Number 2,July - December 2019. Page 203-212

\section{CONCLUSION}

Bureaucratic reforms have significantly influenced organizational performance at the Secretariat General of the Ministry of Education and Culture. The dimensions of bureaucratic reforms have quite varied impacts. The basis of reform dimension shows the best result among others. This shows that bureaucratic reforms are characterized by a strong basis of reforms by strengthening the staff as service providers. The agent of reform dimension shows a good performance. The support of all elements including the staff in carrying out bureaucratic reforms is a required prerequisite. This support leads to the strengthening of Human Resources as an agent of bureaucratic reforms. The bureaucratic environment dimension shows a good result. The findings show that a conducive environment has an important role in supporting the success of the bureaucratic reform that the Ministry of Education and Culture wants to achieve.

\section{REFERENCES}

Aji, M. Q. W., Heru, B., \& Turmudzi, D. (2013). Impact of bureaucracy reforms and cultural organization to the performance of organization secretariat general ministry of education and culture. Pasundan University.

Aneta, A., Aneta, Y., \& Dama, H. (2018). Institutional Problems in Regional Public Services. Jurnal Ilmiah Ilmu Administrasi Publik, 8(2), 79-86. https://doi.org/10.26858/jiap.v8i2.7877

Caiden, G. E. (2014). Administrative reform comes of age (Vol. 28). Walter de Gruyter GmbH \& Co KG.

Dwiyanto, A. (2013). Mengembalikan kepercayaan publik melalui reformasi birokrasi. Gramedia Pustaka Utama.

Cheung, A. B. L. (2005). The politics of administrative reforms in Asia: Paradigms and legacies, paths and diversities. Governance, 18(2), 257-282. https://doi.org/10.1111/j.1468-0491.2005.00275.x

Gibson, Ivancevich., Donnely. 1997, Organisasi, Perilaku, Struktur, Proses, alih bahasa Wahid, Jakarta: Erlangga.

Kassay, A. (1998). Administration and efficiency - bureaucratic reform: The case of Jordan. Mediterranean Politics, 3(3), 52-62. https://doi.org/10.1080/13629399808414665

Lee, H. B., \& Samonte, A. G. (Eds.). (1970). Administrative reforms in Asia. Eastern Regional Organization for Public Administration.

Miftah, T. (2008). Birokrasi Pemerintah Indonesia di Era Reformasi. Edisi Pertama, Cetakan ke-1, Kencana Pranada Media Group, Jakarta.

Morgan, G. (1997). Images of organization. Thousands Oaks. Cal.: Sage Publications 
Morgan, G. (2011). Reflections on images of organization and its implications for organization and environment. Organization and Environment, 24(4), 459-478. https://doi.org/10.1177/1086026611434274

Mukhtar, M. I. (2015). The public manager, the structure of public institution, and implementation: The 2002-2012 finnish senior bureaucratic manager reform. Teaching Public Administration, 33(1), 40-61. https://doi.org/10.1177/0144739414532283

Paskarina, C. (2017). The making of competitive bureaucracy: A case of bureaucratic reform in West Java province. Cogent Social Sciences, 3(1), 1-13. https://doi.org/10.1080/23311886.2016.1273748

Prasojo, E., \& Kurniawan, T. (2008). Bureaucracy Reform and Good Governance: the case of the best practices from several regions in Indonesia. Symposium A Quarterly Journal In Modern Foreign Literatures, 1-15. Retrieved from https://scholar.google.com/scholar?oi=bibs\&cluster=360656420083251686\&btnI=1\&hl=i d

Robbins, S. P. (1998). Organisation Behaviour. Eight Edition.

Robbins, S. P. (2003). Perilaku Organisasi.(judul asli: Organizational Behavior Concept, Controversies, Applications 8th edition) Jilid 1. Penerjemah Hadyana Pujaatmaka. Jakarta: PT. Prenhallindo.

Robbins, S. P. (2009). organisational behaviour in Southern Africa. Pearson South Africa.

Robbins, S. P. (1990). Organization Theory: Structures, Designs, And Applications, 3/e. Pearson Education India.

Sobirin, A. (2007). Budaya Organisasi: Pengertian, makna dan aplikasinya dalam kehidupan organisasi. Yogyakarta: UPP, STIM YKPN.

Sondang, S. P. (1995). Teori Pengembangan Organisasi. Jakarta, Bumi Aksara, Sinar Grafika Offset.

Tandi Datu, T., \& Nawawi, H. J. (2014). Implementation of good governance and bureaucratic reform in Indonesia. International Journal of Academic Research, 6(3), 5-9. https://doi.org/10.7813/2075-4124.2014/6-3/b.1

Tjokroamidjojo, Bintoro. 1997. Perencanaan Pembangunan. Jakarta: Gunung Agung

Turner, M., \& Hulme, D. (1997). Governance, administration and development: Making the state work. Macmillan International Higher Education.

Yusriadi, \& Misnawati. (2017). Reformasi Birokrasi dalam Pelayanan Publik. Jurnal Ilmiah Ilmu Administrasi Publik, 7(2), 99-108. Retrieved from http://ojs.unm.ac.id/iap/article/view/4954 
212 Jurnal Ilmiah Ilmu Administrasi Publik: Jurnal Pemikiran dan Penelitian Administrasi Publik Volume 9 Number 2,July - December 2019. Page 203-212 